\title{
IDENTIFIKASI KERENTANAN DAN SEBARAN LONGSOR LAHAN SEBAGAI UPAYA MITIGASI BENCANA DI KECAMATAN BENER KABUPATEN PURWOREJO
}

\author{
Muhammad Nursa'ban \\ mnsaban@yahoo.com \\ FISE Universitas Negeri Yogyakarta
}

\begin{abstract}
The objectives of this research are to: Investigating the level of landslide susceptibility and identifying the distribution of landslide susceptibility locations in Bener district Purworejo regency. Land units were chosen as the sample using the purposive area sampling technique. Eleven land units were obtained by overlay maps of slope, geology, and soil types. Data collecting was conducted with observation method and documentation to be analyzed by qualitative deskriptif. Findings shown that (1) the level of landslide susceptibility that is in four categories are low, medium, high, and very high. The distributions of low landslide susceptibility covered about 24042750,21 $\mathrm{m}^{2}$ (3 land units). The medium categories covered about 67768254,22 $\mathrm{m}^{2}$ (4 land units). High categories covered about $4125389,95 \mathrm{~m}^{2}$ (2 land units). The very high categories covered about $6256242,28 \mathrm{~m}^{2}$ (2 land units)
\end{abstract}

Key words: landslide, susceptibility, mitigation, hazard, Menoreh.

\section{PENDAHULUAN}

\section{Latar Belakang}

Indonesia sering dikejutkan dengan adanya bencana longsor lahan di beberapa daerah. Bencana ini tidak hanya menimbulkan korban jiwa, lebih dari itu infrastruktur di daerah tersebut juga terganggu fungsinya. Bencana longsor lahan tersebut terjadi tidak lepas dari keadaan alam dan perilaku manusia. Posisi Indonesia yang terletak pada pertemuan tiga lempeng yaitu lempeng benua Australia, lempeng Benua Eurasia, dan lempeng Samudera Pasifik, sehingga terbentuklah jalur gunung api aktif dan jalur gempa bumi. Adanya tumbukan lempeng-lempeng tersebut maka terjadi zona penunjaman yang merupakan jalur gempa bumi dan membentuk undulasi di busur kepulauan dengan kemiringan terjal sampai sangat terjal. Disamping itu, Indonesia juga terletak di daerah tropis dengan curah hujan yang tinggi, dan memiliki topografi yang bervariasi. Secara geologis, geomorfologis, dan klimatologis Indonesia selalu dihadapkan pada bencana alam seperti: letusan gunung api, gempa bumi, longsor lahan, dan banjir. Selain itu faktor manusia juga dalam mengelola lahan turut menjadi pemicu terjadi bencana.

Salah satu bencana alam yang sering terjadi di Indonesia adalah longsor lahan. Frekuensi kejadian atau kemungkinan terjadinya bencana longsor lahan relatif 
lebih besar dari pada frekuensi kemungkinan terjadinya bencana geologi yang lain. Titik-titik kejadian longsor lahan juga tersebar luas di seluruh wilayah Kepulauan Indonesia daripada sebaran lokasi kejadian bencana geologi lain. David J. James (1978); yang dikutip Dumanski (1997: 244) memberikan definisi longsor lahan"...is the process by which earth materials (bedrocks, unconsolidated sediments and soils) are transported down slopes by gravity". Thornbury (1969: 76) mendefinisikan longsor lahan sebagai gerakan massa dari rombakan batuan yang tipe gerakannya meluncur atau menggeser (sliding/slipping), berputar (rotational) yang disebabkan oleh gaya gravitasi sehingga gerakannya lebih cepat dan kandungan airnya lebih sedikit.

Longsor lahan menurut Direktorat Geologi dan Tata Lingkungan (1981) yaitu suatu produk gangguan keseimbangan lereng yang menyebabkan bergeraknya massa tanah dan batuan ke tempat yang lebih rendah. Gerakan ini dapat terjadi pada tanah yang hambatan tanah/batuannya lebih kecil dibanding dengan berat massa tanah/batuan itu sendiri. Hal ini secara sederhana dapat dilihat pada Gambar 1.

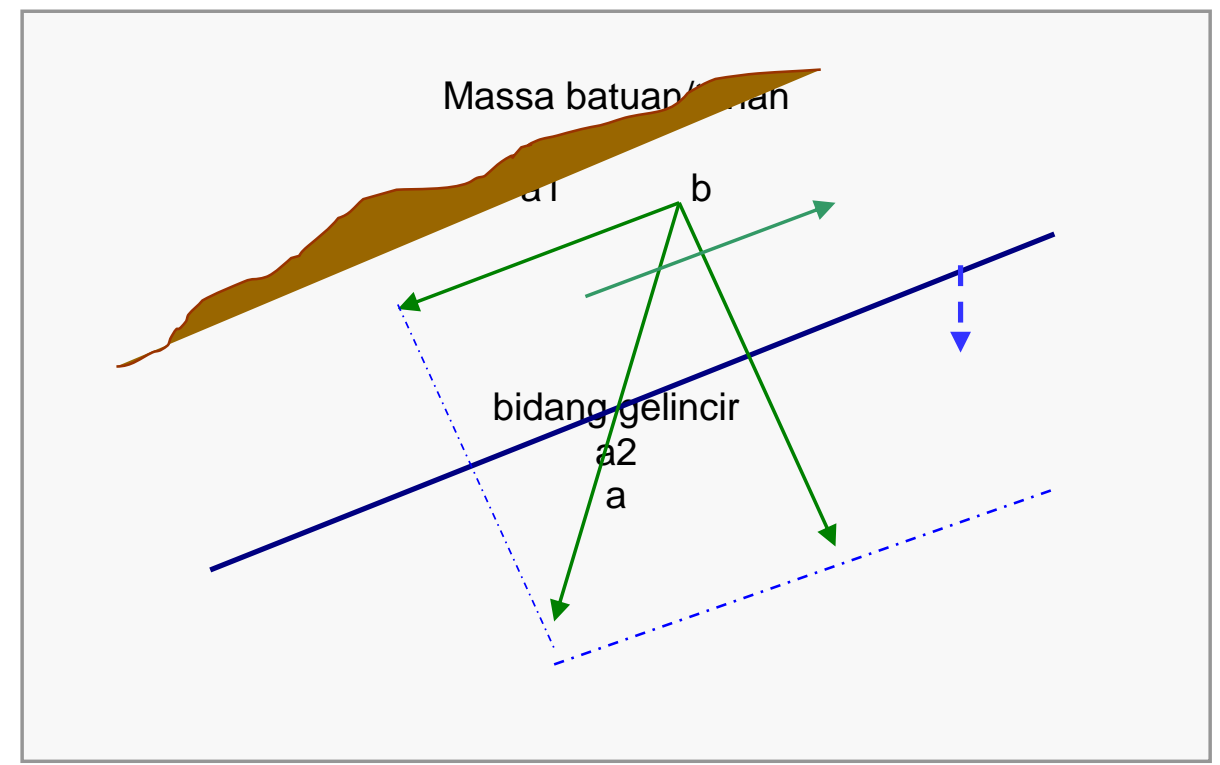

Keterangan : a = gaya berat massa pada titik beratnya; a1 dan a2 = vektor berat; besarnya tergantung dari sudut lereng; $b=$ gaya hambatan; Jika $b<a 1=$ terjadi longsor lahan

Gambar 1. Mekanisme longsor lahan pada lereng

(Direktorat Geologi Tata Lingkungan, 1981 dalam Thahjono 2003: 19)

Sitanala Arsyad (1989: 23) menyatakan longsor lahan akan terjadi apabila terdapat tiga keadaan, yaitu: (1) Terdapat lereng yang cukup curam sehingga massa tanah dapat bergerak atau meluncur secara cepat ke bawah. (2) Adanya lapisan di bawah permukaan massa tanah, yang kedap air dan lunak, yang akan menjadi bidang luncur. (3) Adanya cukup kandungan air dalam tanah sehingga massa tanah yang tepat di atas lapisan kedap tersebut menjadi jenuh.

Berdasarkan data yang dihimpun Direktorat Vulkanologi dan Mitigasi Bencana Geologi, Direktorat Jendral Geologi dan Sumber Daya Mineral (2003), 
setiap tahun beberapa wilayah di Indonesia mengalami longsor lahan. Longsor lahan tersebut mengakibatkan kerugian materi dan juga korban jiwa. Kejadian longsor lahan umumnya berskala kecil, tidak sehebat gempa bumi, tsunami maupun gunung meletus sehingga perhatian pada masalah ini umumnya tidak terlalu besar, tambah lagi bahaya bencana longsor lahan kurang diperhatikan dalam perencanaan pembangunan. Keadaan alam yang bergunung-gunung di setiap wilayahnya, Indonesia berpotensi mengalami longsor lahan. Salah satu upaya untuk mengurangi dan mencegah terjadinya longsor lahan yaitu dengan mengetahui persebaran daerah yang rawan terhadap longsor lahan. Setiap lahan memiliki tingkat kerentanan longsor lahan yang beragam. Hal tersebut dipengaruhi oleh beberapa faktor penyebab. Cook dan Dornkampm (1994: 148) menyatakan faktor penyebab longsor lahan meliputi faktor pasif dan faktor aktif. Faktor pasif mengontrol terjadinya longsor lahan sedangkan faktor aktif pemicu terjadinya longsor lahan (Thornbury, 1969). Faktor pasif meliputi faktor topografi, keadaan geologis/litologi, keadaan hidrologis, tanah, keterdapatan longsor sebelumnya dan keadaan vegetasi. Faktor aktif yang mempengaruhi longsor lahan diantaranya aktivitas manusia dalam penggunaan lahan dan faktor iklim.

Salah satu wilayah di Indonesia yang sering mengalami bencana longsor lahan adalah Kecamatan Bener di Kabupaten Purworejo. Secara topografis wilayah kecamatan ini terletak di Perbukitan Menoreh. Daerah Perbukitan Menoreh ini sebagian besar bertopografi miring sampai sangat terjal dengan jenis batuan beku yang sedang mengalami pelapukan di bagian luarnya menjadi tanah (Monografi Kecamatan Bener tahun 2005), sehingga tingkat pelepasan batuan sangat potensial terjadi. Menurut catatan Kesbanglinmas Kabupaten Purworejo daerah Perbukitan Menoreh merupakan daerah yang rawan bencana longsor lahan.

Kecamatan Bener terdiri dari 28 desa yang tersebar di daerah dataran dan perbukitan. Berdasarkan Peta Kemiringan Lereng Lembar Purworejo (2004) yang dikeluarkan Bappeda Kab. Purworejo Skala 1:50.000 daerah ini sebagian besar bertopografi miring sampai sangat terjal. Kecamatan Bener termasuk dalam Perbukitan Menoreh yang secara fisiografis termasuk dalam Pegunungan Kulon Progo (West Progo Mountains), dengan jenis batuan beku yang terbentuk pada masa tersier. Batuan tersebut sedang mengalami pelapukan di bagian luarnya, menjadi tanah dengan kedalaman tanah yang tebal, sedang dan tipis (Monografi Kecamatan Bener tahun 2005). Menurut Kesbanglinmas Kabupaten Purworejo tahun 2006, Kecamatan Bener merupakan salah satu dari enam kecamatan yang rawan terhadap bencana longsor lahan di Kabupaten Purworejo (http://kompas.com/kompas-cetak/0612/28/).

Beberapa tahun belakangan ini terjadi beberapa kali bencana longsor lahan di Kecamatan Bener. Pada tahun 2004 sedikitnya 15 orang meninggal dunia dan kerusakan material seperti permukiman, lahan pertanian, dan jalur transportasi. Pada tahun 2006 ditemukan sedikitnya lima rumah terbenam dan tiga rumah rusak serta dua orang meninggal (Kompas, 29 Desember 2006). Tahun 2007 dan 2008, kejadian longsor lahan di daerah ini terus berlanjut dan mengakibatkan adanya korban. Menurut data Direktorat Vulkanologi dan Mitigasi Bencana Longsor Geologi (DVMBG) Bandung dalam Harian Kedaulatan Rakyat tanggal 26 
Desember 2001 menyebutkan bahwa keadaan topografi daerah Purworejo merupakan daerah yang cukup rentan terhadap bencana longsor lahan.

Berdasarkan survei yang dilakukan penulis menunjukkan bahwa faktor-faktor penyebab longsor lahan dapat dijumpai di daerah tersebut. Kemiringan lereng bervariasi dari datar sampai sangat terjal. Secara geologis tersusun atas batuan andesit, breksi andesit, aglomerat, tuf lapili, konglomerat, batu pasir dan batu gamping. Penggunaan lahannya juga bervariasi seperti kebun, tegalan, permukiman, sawah dan belukar. Tingkat curah hujan di lokasi ini kategori tinggi yakni, 2500-3000 mm/th (Peta curah hujan Purworejo, 2006). Dengan keadaan bentuk lahan, batuan, penggunaan lahan, curah hujan dan jenis tanah yang beragam menyebabkan tingkat kerentanan longsor lahan di daerah Perbukitan Menoreh bervariasi. Aktivitas manusia yang kurang memperhatikan keseimbangan lingkungan, seperti penggundulan hutan di daerah berlereng curam untuk keperluan pertanian, pemotongan tebing untuk jalan, pembuatan rumah di perbukitan yang berlereng curam dan pembebanan yang berlebihan pada lereng untuk permukiman atau pendirian bangunan diindikasikan menjadi pendorong terjadinya longsor lahan di daerah tersebut.

\section{Kerentanan longsor lahan}

Kerentanan longsor lahan menggambarkan keadaan kecenderungan lereng alami atau potensi suatu medan untuk terjadinya gerakan massa atau ketidakseimbangan yang dibentuk oleh lingkungan fisik maupun non fisik. Penilaian tingkat bahaya kerentanan longsor lahan menggunakan pendekatan Satuan Unit Lahan sebagai satuan analisis. Satuan Unit Lahan (SUL) menunjukan kelas suatu bentuk lahan sejenis dalam hubungannya dengan karakteristik satuan unit lahan tersebut. Penentuan tingkat kerentanan ini dilakukan dengan cara kualitatif dan kuantitatif. Cara kualitatif yaitu dengan cara menafsirkan keadaan bentuk permukaan bumi (morfologi), keadaan batuan (geologis), keadaan tanah, keadaan perairan (hidrologis) dan penggunaan lahan. Cara kuantitatif yaitu dengan pemberian skor atau pengharkatan karakteristik unit lahan yang telah ditentukan melalui tumpang susun peta.

\section{Mitigasi Bencana Alam (Hazard Mitigation)}

Menurut Sudibyakto (1985: 3) mitigasi bencana alam merupakan tindakan untuk mengurangi dampak bencana dan hampir sama dengan kegiatan pencegahan. Ditambahkan oleh Sutikno (1994: 23) mitigasi adalah suatu tindakan sebelum bencana terjadi untuk mengurangi seminimal mungkin kerugian harta benda atau korban jiwa. Pada prinsipnya upaya mitigasi dapat dilakukan melalui pendekatan non-struktural seperti peraturan perundangan, penyuluhan, insentif, dan pengembangan sistem peringatan demi bahaya. Tindakan mitigasi terdiri atas mitigasi pasif dan aktif. Mitigasi pasif berupa pengembangan tindakan-tindakan seperti peraturan tentang bangunan, tata guna lahan, tata ruang kota, pemasangan rambu dan tanda bahaya. Mitigasi aktif mencakup tindakan-tindakan yang memerlukan kontak langsung dengan penduduk yaitu melalui penyuluhan sosial, pemugaran rumah, relokasi penduduk dari daerah rawan bencana ke daerah yang 
aman. Mitigasi aktif tidak akan berfungsi tanpa mitigasi pasif (Soetarso, 1997; dalam Sudibyakto 1985: 3).

Pusat Studi Bencana Alam (PSBA) UGM (2001) menyatakan upaya mitigasi bencana alam longsor lahan dapat dilakukan dengan tiga cara yaitu 1) mitigasi bencana alam longsor lahan secara fisik berupa tindakan pemotongan tebing dan penggalian batuan, pembuatan talud, pembuatan kawat pengikat batuan yang lapuk, pembuatan teras sesuai kontur, teras bangku, penanaman pohon-pohon, dan pembuatan saluran. 2) secara sosial upaya pencegahan dan penanggulangan bencana longsor lahan dengan menekan sedikit mungkin atau tanpa ada korban jiwa dan kerugian harta benda melalui kegiatan penyelamatan yaitu, pemindahan penduduk secara permanen dan pemindahan penduduk sementara (evakuasi saat terjadi bencana). 3) mitigasi bencana alam longsor lahan secara vegetatif yaitu dengan memperhatikan keadaan vegetasi meliputi, pemilihan jenis vegetasi yang sesuai dan pengaturan jarak tanaman.

\section{METODE PENELITIAN}

Penelitian ini merupakan penelitian deskriptif eksploratif dengan variabel terikat yaitu tingkat kerentanan longsor lahan dan variabel bebas yaitu keadaan fisik lahan. Keadaan fisik lahan ini yaitu: 1) topografi lahan berupa kemiringan lereng. 2) keadaan geologis berupa tingkat pelapukan batuan. 3) Keadaan Tanah, meliputi: Kedalaman efektif tanah, Solum tanah, Tekstur tanah, dan Permeabilitas tanah. 4) keadaan iklim berupa curah hujan. 5) kerapatan vegetasi, 6) aktivitas manusia berupa penggunaan lahan.

Populasi penelitian ini yaitu lahan di Perbukitan Menoreh yang masuk secara adminitratif dalam wilayah Kecamatan Bener. Sampel dalam penelitian ini berupa satuan unit lahan (land unit). Teknik pengambilan sampel yaitu purposive area sampling. Satuan Unit Lahan (SUL) diperoleh dengan cara tumpang susun (overlay) 3 peta tematik yaitu, peta kemiringan lereng, jenis tanah, peta geologi daerah penelitian. Nama-nama peta tersebut kemudian dijadikan sebagai dasar penamaan pada setiap satuan unit lahan. Nama-nama pada setiap satuan unit lahan yang berupa huruf dan angka merupakan urutan nama-nama peta yang digunakan yaitu diawali dari jenis tanah $(\mathrm{L}=$ latosol, $\mathrm{A}=$ Aluvial $)$, kondisi geologi (Ad = Andesit, $\mathrm{Al}=$ Aluvium, $\mathrm{D}=$ Dasit, $\mathrm{H}=$ Halang, $\mathrm{J}=$ Jonggrangan, $\mathrm{Kb}=\mathrm{Kebo}$ butak), dan kemiringan lereng $\left(\mathrm{K} 1=0^{\circ}-15^{\circ}, \mathrm{K} 2=>15^{\circ}-50^{\circ}, \mathrm{K} 3=>50^{\circ}\right)$. Hasil overlay diperoleh 11 jenis Satuan Unit Lahan yang tersebar di 66 lokasi yang tersebar di Kecamatan Bener.

Metode pengumpulan data yaitu observasi mengenai penggunaan lahan, kerapatan vegetasi, dan tingkat pelapukan batuan, pengukuran kedalaman efektif tanah, solum tanah, dan kemiringan lereng. Uji laboratorium dilakukan untuk mengetahui tekstur dan permeabilitas tanah, serta dokumentasi dilakukan dengan jalan mencatat dan menyalin berbagai dokumen antara lain: 1). monografi kecamatan, 2). data curah hujan kurun waktu 10 tahun, 3) peta, dan 4). data bencana alam. Data-data yang telah terkumpul, kemudian diolah dengan cara kualitatif dan kuantitatif. Cara kualitatif yaitu menafsirkan variabel pendukung 
terjadinya longsor lahan pada tiap satuan unit lahan untuk mengetahui karakteristik lahan yang berpengaruh terhadap longsor lahan di daerah penelitian meliputi: (a) faktor aktif yaitu data curah hujan dan aktivitas manusia berupa penggunaan lahan. (b) faktor pasif di antaranya kemiringan lereng, tekstur tanah, permeabilitas, kedalaman efektif tanah, solum tanah, tingkat pelapukan batuan, dan kerapatan vegetasi. Cara kuantitatif dilakukan melalui teknik Overlay untuk menentukan satuan unit lahan. Satuan Unit Lahan kemudian diberi skor sesuai dengan kriteria penilaian yang telah ditentukan. Tujuannya untuk menentukan atau menilai tingkat kerentanan tanah longsor di daerah penelitian. Penilaian ini didasarkan pada besar kecilnya pengaruh variabel pendukung tingkat kerentanan tanah longsor di daerah penelitian. Tingkat kerentanan tanah longsor ditunjukkan oleh jumlah harkat atau skor secara keseluruhan dari masing-masing parameter pendukung terjadinya tanah longsor. Langkah berikutnya yaitu membuat tabel klasifikasi untuk memasukan data yang telah diperoleh dari hasil tumpang susun peta (overlay) dan dari data yang diperoleh di lapangan. Langkah berikutnya membuat interval kelas penilaian tingkat kerentanan tanah longsor dengan empat tingkat kerentanan. Pembuatan interval kelas dengan cara menghitung jumlah nilai maksimal pembobotan dikurangi dengan jumlah nilai minimal pembobotan. Hasil pengurangan ini di bagi dengan jumlah kelas yang diinginkan, maka akan menghasilkan interval kelas kerentanan. Berdasarkan pembobotan parameter pengaruh longsor lahan kemudian dibuat interval kelas:

$$
\text { Interval kelas }=\frac{36-9}{4}=6,75
$$

Berdasarkan hasil interval kelas kerawanan tersebut, maka ditentukan kelas kerentanan longsor lahan sebagai berikut :

Tabel 1. Kriteria Kelas Kerentanan Longsor Lahan

\begin{tabular}{cccc}
\hline No & Interval total skor & Kriteria kerentanan & Kelas \\
\hline 1 & $9-15$ & Rendah & I \\
\hline 2 & $16-22$ & Sedang & II \\
\hline 3 & $23-29$ & Tinggi & III \\
\hline 4 & $30-36$ & Sangat tinggi & IV \\
\hline
\end{tabular}

Sumber: Data primer 2009

\section{HASIL DAN PEMBAHASAN}

Deskripsi data hasil penelitian ini menunjukkan tingkat potensi kerentanan pada setiap satuan unit lahan di daerah penelitian. Hasil analisis diperoleh data bahwa sebagian besar (9 lokasi SUL) masuk dalam kategori sangat tinggi yaitu satuan unit lahan LAdK3 (1 lokasi) dan LKbK3 (8 lokasi). Satuan unit lahan kategori tinggi sebanyak 8 lokasi yaitu LAdK1 (3 lokasi) dan LAdK2 (5 lokasi). Kategori sedang sebanyak 23 lokasi yang tersebar dalam satuan unit lahan LAlK2 (4 lokasi), LHK2 (2 lokasi), LKbK2 (15 lokasi), dan LSK2 (2 lokasi). Sementara kategori rendah sebanyak 26 lokasi SUL yaitu LAlK1 (3 lokasi), LKbK1 (19 
lokasi), dan LSK1 (4 lokasi). Luasan wilayah satuan unit lahan kategori sedang merupakan wilayah paling banyak di Kecamatan Bener yaitu 67.768.254,219 m². Data lengkap mengenai persebaran tingkat kerentanan longsor lahan ditunjukkan tabel 2. Gambaran mengenai persebaran tingkat kerentanan daerah longsor lahan ditunjukkan gambar 2.

Tabel 2. Klasifikasi Tingkat Kerentanan Longsor Lahan di Kecamatan Bener

\begin{tabular}{|c|c|c|c|c|c|}
\hline No & $\mathbf{S} \mathbf{U} \mathbf{L}$ & $\mathbf{J m l}$ & Luas (m) & kategori & Nama Desa \\
\hline 1 & LAdK1 & 3 & 835056,011 & $\overline{\mathrm{T}}$ & $\begin{array}{l}\text { Cacaban Lor, Kedungloteng, Pekacangan, } \\
\text { Kaliwader, Cacabn Kidul, Wadas }\end{array}$ \\
\hline 2 & LAdK2 & 5 & 3290333,94 & $\mathrm{~T}$ & $\begin{array}{l}\text { Cacaban Lor, Kedungloteng, Pekacangan, } \\
\text { Kaliwader, Kalitapas, Cacabn Kidul, Wadas }\end{array}$ \\
\hline 3 & LAdK3 & 1 & 50833,495 & ST & Kalitapas \\
\hline 4 & LAlK1 & 3 & 6375148,72 & $\mathrm{R}$ & $\begin{array}{l}\text { Kedung Loteng, Kaliwader, Kaliurip, } \\
\text { Kedung Pucang, Sendang Sari, KaliBoto, } \\
\text { Guntur, Bener }\end{array}$ \\
\hline 5 & LAlK2 & 4 & 1285811,19 & $S$ & $\begin{array}{l}\text { Kedung Loteng, Kaliwader, Kaliurip, } \\
\text { Kedungpucang, Sendangsari, Guntur, Bener }\end{array}$ \\
\hline 6 & LHK2 & 2 & 411666,011 & $S$ & Guntur \\
\hline 7 & LKbK1 & 19 & 13485432,7 & $\mathrm{R}$ & $\begin{array}{l}\text { Sidomukti, Cacaban Lor, Mangunsari, } \\
\text { Kalijambe, Kamijoro, Medono, Jati, Bleber, } \\
\text { Kedung Loteng, Pekacangan, Kaliwader, } \\
\text { Sukowuwuh, Limbangan, Legetan, Cacaban } \\
\text { Kidul, Wadas, Guntur, Bener, dan Kertosari }\end{array}$ \\
\hline 8 & LKbK2 & 15 & 60473661,8 & $S$ & $\begin{array}{l}\text { Ngasinan, Nglaris, Sidomukti, Cacaban, } \\
\text { Mangunsari, Kalijambe, Kamijoro, Medono, } \\
\text { Jati, Bleber, Kedungloteng, Pekacangan, } \\
\text { Benowo, Kaliwader, Kalitapas, Guntur, } \\
\text { Wadas, Bener, Kertosari, Sukowuwuh, } \\
\text { Limbang, Kaliurip, Legetan, Cacaban }\end{array}$ \\
\hline 9 & LKbK3 & 8 & 6205408,79 & ST & $\begin{array}{l}\text { Nglaris, Sidomukti, Medono, Pekacangan, } \\
\text { Benowo, Kalitapas, Sukowuwuh, Cacaban } \\
\text { Kidul }\end{array}$ \\
\hline 10 & LSK1 & 4 & 4182168,82 & $\mathrm{R}$ & $\begin{array}{l}\text { Kali Urip, Kedungpucang, Kaliboto, } \\
\text { Legetan, Guntur, sendang sari, Karangsari, } \\
\text { Bener, Kertosari }\end{array}$ \\
\hline \multirow[t]{2}{*}{11} & LSK2 & 2 & 5597115,18 & $S$ & $\begin{array}{l}\text { Sendangsari, Kaliboto, Legetan, Guntur, } \\
\text { Karangsari, Bener, Kertosari }\end{array}$ \\
\hline & Jumlah & 66 & 102192637 & & \\
\hline
\end{tabular}

\section{Tingkat Potensi Kerentanan Longsor lahan di Daerah Penelitian}

Hasil observasi dan pengukuran di lapangan yang dilakukan terhadap 9 variabel pendukung tingkat kerentanan longsor lahan di daerah penelitian, yang dianalisis berdasarkan karakteristik satuan lahan diperoleh empat kelas tingkat kerentanan longsor lahan yaitu, tingkat kerentanan longsor lahan rendah, sedang, tinggi, dan sangat tinggi.

Tingkat kerentanan longsor lahan kategori rendah di daerah penelitian terdapat tiga satuan unit lahan yang terletak di 26 lokasi dengan luas wilayahnya mencapai 
$24042750,21 \mathrm{~m}^{2}$. Satuan unit lahan ini relatif datar dengan kemiringan kurang dari $15^{\circ}$, tekstur tanah berupa geluh, permeabilitas kategori cepat yaitu $>12,5 \mathrm{~cm} / \mathrm{jam}$, solum sangat tipis $\leq 25 \mathrm{~cm}$, pelapukan batuan ringan batuan belum mengalami perubahan warna dan perubahan warna baru terjadi di permukaan batuan, sedikit dinding terjal, penggunaan lahan hutan sejenis atau kebun campuran, vegetasi cukup rapat $75-100 \%$, serta struktur perlapisan sangat baik.

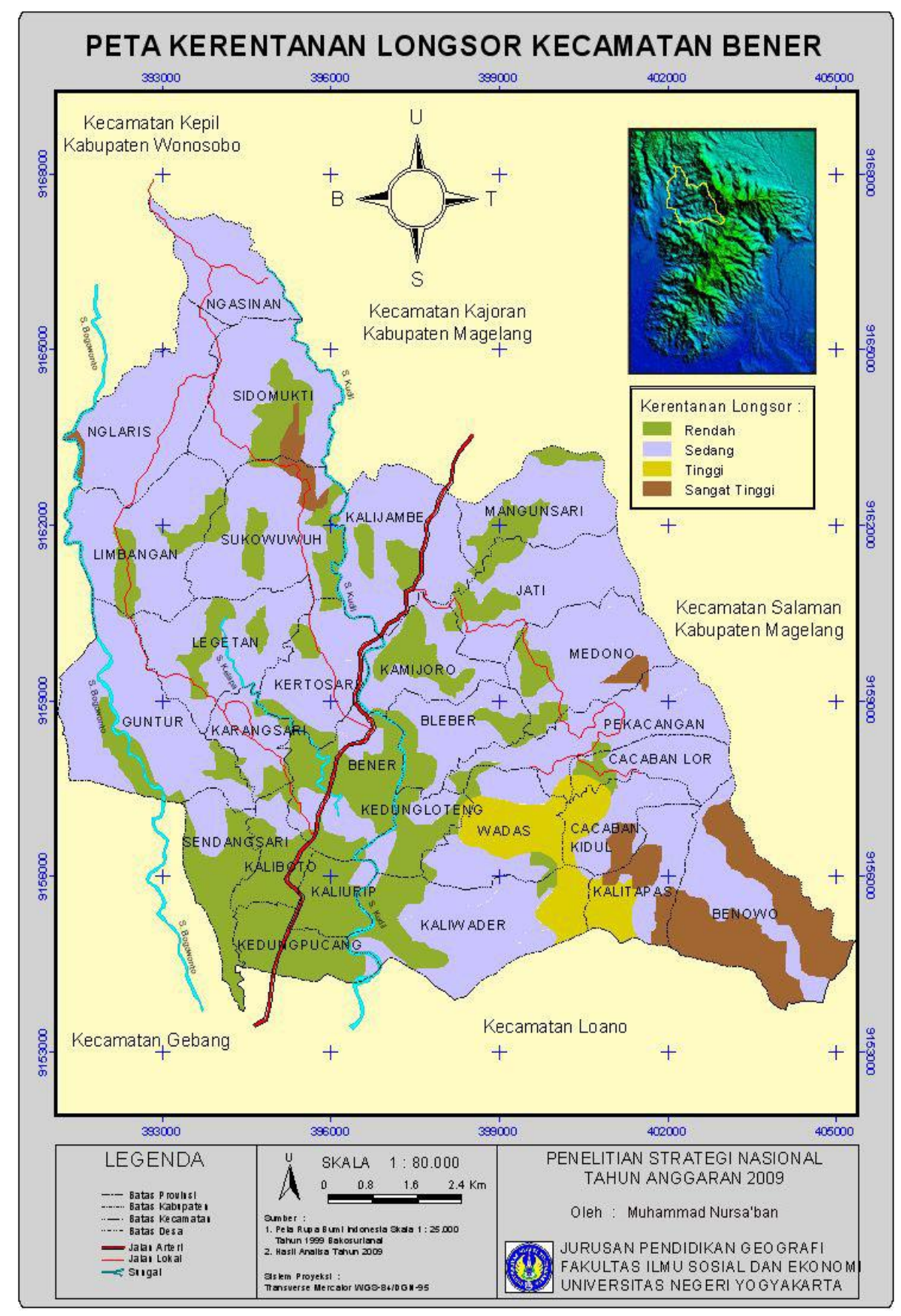

Gambar 2. Peta Kerentanan Longsor Lahan di Kecamatan Bener 
Tingkat kerentanan longsor lahan kategori sedang di daerah penelitian terdapat empat jenis satuan unit lahan yang terletak di 23 lokasi dengan luas wilayahnya mencapai $67768254,22 \mathrm{~m} 2$. Satuan unit lahan kategori ini memiliki kemiringan relatif tinggi sekitar $>15-27^{\circ}$ dengan tekstur tanah sedikit dijumpai kandungan pasir tetapi mengandung lempung cukup besar sehingga mampu menyimpan air yang berpotensi longsor. Permeabilitas tanah relatif cepat sehingga mampu meloloskan air. Tingkat pelapukan batuan relatif baik untuk menahan laju longsor tetapi masih nampak belum sempurna. Kedalaman efektif tanah, solum tanah dan kerapatan vegetasi juga mampu menjadikan satuan unit lahan ini agak terhindar mengalami longsor. Meskipun demikian satuan unit lahan kategori ini berpotensi longsor dengan penggunaan lahan berupa sawah pada daerah yang agak terjal. Kenampakan longsor lahan yang terjadi sebelumnya belum banyak dijumpai di daerah ini, baik dalam skala kecil maupun besar. Peristiwa longsor lahan yang terjadi di daerah ini banyak ditemukan di beberapa ruas jalan. Hal tersebut dikarenakan variabel lahan yang berpengaruh terhadap longsor lahan pada daerah ini kurang mendukung untuk terjadinya longsor lahan. Longsor yang terjadi sebagian besar dipengaruhi oleh aktivitas manusia dan intensitas hujan yang tinggi.

Tingkat kerentanan longsor lahan kategori tinggi di daerah penelitian tersebar pada dua jenis satuan unit lahan yang terletak di 8 lokasi dengan luas wilayahnya mencapa 4125389,95 $\mathrm{m}^{2}$. Karakteristik satuan unit lahan kategori ini yaitu; kemiringan lereng antara $27-39^{\circ}$, tekstur tanah didominasi oleh lempung pasiran, permeabilitas agak lambat $0,8-1,8 \mathrm{~cm} / \mathrm{jam}$, sementara solum tanah tebal antara $100-115 \mathrm{~cm}$, pelapukan batuan sangat lanjut dengan tampak luar sudah menjadi tanah, tetapi susunan batuan asal masih bertahan. Penggunaan lahan diperuntukkan bagi permukiman meskipun itu di daerah lereng perbukitan terjal dengan kerapatan vegetasi rapat-sangat rapat (15-25\%). Walaupun demikian daerah yang berlereng curam pada daerah ini sebagian besar digunakan untuk lahan tegalan sehingga rentan terhadap longsor lahan. Kondisi batuan yang terdapat di daerah ini telah mengalami pelapukan yang lanjut sampai sangat lanjut. Batuan yang ada sebagian besar telah melapuk menjadi tanah. Pada beberapa tempat banyak ditemukan mata air dan bekas penggalian tebing maupun pemotongan lereng yang dilakukan para penduduk. Hal ini akan menyebabkan terjadinya pendangkalan di lereng bagian atas dan di kaki lereng. Kondisi demikian akan memudahkan terjadinya aliran permukaan dan penggelinciran tanah ke bagian bawah, apalagi diikuti oleh curah hujan yang cukup tinggi.

Tingkat kerentanan longsor lahan kategori sangat tinggi hanya terdapat pada dua jenis satuan unit lahan yang tersebar pada 9 lokasi dengan luas wilayahnya mencapai $6256242,28 \mathrm{~m}^{2}$. Kemiringan lereng pada setiap satuan unit lahan sangat curam melebihi $40^{\circ}$, tekstur tanah berupa lempung geluh, lempung pasiran sampai lempung oleh karena itu permeabilitas tanah yang ditemukan termasuk kelas lambat sampai sangat lambat $<0,5 \mathrm{~cm} / \mathrm{jam}$. Solum tanah $>120 \mathrm{~cm}$ dan telah terjadi pelapukan batuan sempurna yang berubah menjadi tanah dengan susunan jaringan asal telah. Sebagian besar penggunaan lahan berupa permukiman sampai tegalan dan sawah pada lereng-lereng. Vegetasi penutup nampak sangat jarang $>15 \%$ lebih banyak medan terbuka bergelombang di perbukitan. Tingkat curah hujan 
yang lebih tinggi dibandingkan bagian utara menyebabkan satuan unit lahan kategori ini sangat rentan terhadap longsor lahan.

\section{Upaya mitigasi bencana alam longsor lahan}

Berdasarkan hasil analisis untuk tingkat kerentanan longsor lahan di daerah penelitian, maka dapat dilakukan berbagai upaya mitigasi bencana. Studi kerentanan yang menghasilkan tingkat kerentanan longsor lahan pada setiap satuan unit lahan pada bagian awal merupakan prediksi terhadap kejadian longsor lahan yang dapat berakibat bencana bagi penduduk sekitar. Kategorisasi yang diberikan peneliti untuk masing-masing tingkat kerentanan bertujuan untuk menginformasikan kemungkinan kejadian longsor yang dapat berakibat bencana sesuai tingkatannya. Semakin tinggi potensi kerentanan berdasarkan kategorisasi tersebut maka semakin tinggi kemungkinan terjadinya longsor lahan. Mendasarkan pada hasil yang diperoleh maka dapat dilakukan upaya pencegahan (mitigasi) terhadap kemungkinan yang akan terjadi. Penelitian ini memperhitungkan dua aspek yaitu kondisi alam dan manusia oleh sebab itu upaya mitigasi dapat dilakukan untuk kedua aspek tersebut. Aspek pertama upaya mitigasi terhadap kondisi alam dalam hal ini kondisi fisik alam dan vegetasi, selanjutnya mitigasi untuk manusia atau secara sosial.

Mitigasi secara fisik ini bertujuan memberikan alternatif upaya atau tindakan yang dapat dilakukan dalam penanganan longsor lahan kategori kerentanan sedang sampai sangat tinggi. Sedangkan bagi kelas kategori rendah lebih bisa ditoleransi. Beberapa upaya yang dapat dilakukan antara lain: 1). Mengurangi tingkat kemiringan lereng yang terjal dapat dilakukan pemotongan tebing dan penggalian batuan yang mempunyai stratigrafi horizontal. Kemudian dibuatkan talud/sengkedan pada lereng-lereng untuk mengurangi laju air permukaan (runoff) sehingga daya gerus yang lebih kecil, 2). Pembuatan talud pada tebing jalan dan di sekitar rumah. 3). Pembuatan kawat pengikat batuan yang lapuk dengan kemiringan $>45 \%$. 4). Pembuatan teras sesuai kontur pada perbukitan yang materialnya tidak kompak dan kedalaman lapuk tebal. 5). Teras bangku pada daerah material lapuk tebal. 6). Penanaman pohon-pohon pada lahan dengan kedalaman lapuk dalam. 7). Pembuatan saluran di bagian bawah talud maupun menyerupai talud di sepanjang tebing. Disamping itu dapat dilakukan juga mitigasi secara vegetatif yaitu upaya pencegahan dan penanggulangan bencana alam dengan cara memperhatikan kondisi vegetasi yang ada di daerah terjadinya bencana longsor lahan, meliputi, pemilihan jenis vegetasi yang sesuai dan pengaturan jarak tanaman.

Mitigasi secara sosial berupa upaya pencegahan dan penanggulangan bencana alam dengan menekan sedikit mungkin atau bahkan bila dapat dilakukan tanpa ada korban jiwa dan kerugian harta benda. Hal ini dilakukan dalam dua kategori kegiatan penyelamatan yaitu, pemindahan penduduk secara permanen dan pemindahan penduduk sementara (evakuasi saat terjadi bencana). 


\section{SIMPULAN}

Berdasarkan hasil dan pembahasan, maka simpulan penelitian adalah 1) tingkat kerentanan longsor lahan di Kecamatan Bener Kabupaten Purworejo memiliki empat kelas yaitu rendah, sedang, tinggi, dan sangat tinggi; 2) sebaran tingkat kerentanan longsor lahan di daerah penelitian sebagai berikut :

1. Tingkat potensi kerentanan longsor lahan rendah meliputi jenis satuan unit lahan: LAlK1, LKbK1, LSK1 yang terletak di 26 lokasi dengan luas wilayahnya mencapai $24042750,21 \mathrm{~m}^{2}$

2. Tingkat potensi kerentanan longsor lahan sedang meliputi satuan unit lahan: LAlK2, LHK2, LKbK2, dan LSK2 yang terletak di 23 lokasi dengan luas wilayahnya mencapai $67768254,22 \mathrm{~m} 2$

3. Tingkat potensi kerentanan longsor lahan Tinggi meliputi satuan unit lahan: LAdK1 dan LAdK2 yang terletak di 8 lokasi dengan luas wilayahnya mencapa $4125389,95 \mathrm{~m}^{2}$

4. Tingkat potensi kerentanan longsor lahan sangat tinggi meliputi satuan unit lahan: LAdK3 dan LKbK3 yang terletak di 9 lokasi dengan luas wilayahnya mencapai $6256242,28 \mathrm{~m}^{2}$

\section{DAFTAR PUSTAKA}

Anonim. (2002). Data Bencana Alam Kabupaten Purworejo. Purworejo: Badan Kesbanglinmas Kabupaten Purworejo.

_ . (2002). Monografi Kecamatan Bener. Purworejo: Kecamatan Bagelen.

Cook, R.U. dan Doornkamp, J.C. (1994). Geomorphology in Enviromental Management - and New Introduction. Amsterdam: Elsevier.

Dumanski, (1997), Criteria and Indicator for Land Quality Management. In ITC Journal. 1997-3/4.243-247

Pusat Studi Bencana Alam UGM dan Bappeda Kabupaten Kulon Progo. (2001). Penyusunan Sistem Informasi Penanggulangan Bencana Alam Tanah Longsor di Kabupaten Kulon Progo. Yogyakarta: PSBA UGM. . (2001). Mitigasi Bencana Alam Tanah Longsor. Yogyakarta: Bappeda Kabupaten Kulon Progo dan PSBA UGM.

Strahler, Arthur N. and Alan H. Strahler. (1987). Modern Physical Geography. New York: John Wiley and Sons, Inc.

Sudibyakto. (1985). Mitigasi Bencana Alam Gunung Berapi. Yogyakarta: Andi Offset.

Sutikno. (1994). "Pendekatan Geomorfologi untuk Mitigasi Bencana Alam Akibat Gerakan Massa Tanah atau Batuan". Proceeding di UGM, 16-17 September. Yogyakarta: Fakultas Geografi UGM.

Thornbury, William D. (1969). Principles of Geomorphology. Amerika Serikat: Departement of Geology Indiana University. http://www.kompas.com/kompas-cetak/0601/03/daerah/2337802.htm. Selasa, 03 Januari 2006\, diakses tanggal 28 Maret 2007 
http://kompas.com/kompas-cetak/0601/01/daerah/233.htm. Minggu, 01 Januari 2006, di akses tanggal 23 Maret 2007.

Media Indonesia online. "Tanah Longsor di Purworejo 2 orang Tewas"

http://mediaindonesia.co.id/berita/0601/02/7658.html. 02 Januari 2006, diakses tanggal 4 April 2007

Pusat Vulkanologi dan Mitigasi Bencana Geologi (2007). Pengenalan Gerakan Tanah. http://www.vsi.com, diakses tanggal 4 Juni 2007. 